\title{
Science Teachers' Perceptions of Personal Science Efficacy Beliefs and Science Teaching in Saudi Arabia, Pakistan, and the United Arab Emirates
}

\author{
Sadia Shaukat ${ }^{1 *}$, Venkat Rao Vishnumolakala ${ }^{2,3}$, Amani K. Hamdan Alghamdi ${ }^{4}$ \\ ${ }^{1}$ Associate Professor, Department of Education, University of Education, Lahore, PAKISTAN \\ 2 Department of Education, College of Arts and Sciences, Abu Dhabi University, Abu Dhabi, UNITED ARAB EMIRATES \\ ${ }^{3}$ School of Molecular and Life Sciences, Curtin University, AUSTRALIA \\ ${ }^{4}$ Professor, College of Education, Curriculum and Pedagogy, Imam Abdulrahman Bin Faisal University, SAUDI ARABIA
}

Received 12 March 2020 - Accepted 27 April 2020

\begin{abstract}
This study sought to explore the science efficacy beliefs of in-service teachers from the Kingdom of Saudi Arabia (KSA) $(n=226)$, Pakistan $(n=130)$, and the United Arab Emirates (UAE) $(n=99)$ by administering the Science Teaching Efficacy Belief Instrument (STEBI-B) in a cross-sectional survey research design. A comparison of the three datasets indicated differences in terms of teachers' personal science teaching efficacy (PSTE) and science teaching outcome expectancy efficacy (STOE). Teachers' academic qualifications and experience showed relevance with the PSTE and STOE of the KSA sample but did not show relevance for UAE and Pakistan. These results have implications for teacher education programs in all three countries, which need to strengthen their teaching content and make science teachers more efficacious in order to bring about positive changes in students' science learning. Other recommendations include: providing culturally tailored teacher education that respects the role of cultural adaptation, nationality, gender, academic qualifications, and years of teaching experience; and introducing effective professional development models to strengthen science teachers' efficacy beliefs.
\end{abstract}

Keywords: in-service teachers, outcome expectancy efficacy, personal science efficacy, selfefficacy, trans-national study

\section{INTRODUCTION}

The exploration of science teachers' efficacy beliefs from educationally emerging trans-national contexts is a topic of interest to many discipline-based education researchers and policy makers. During the last decade in the Gulf Arab States, global educational revolution, internationalization, and economic development have had a substantial positive effect on education systems particularly on science education (Wiseman \& Anderson, 2013). The public education sector of the Gulf States, including the Kingdom of Saudi Arabia (KSA) and the United Arab Emirates (UAE), has also invested in the physical infrastructure of schools, increased the number of teachers, and, more recently, invested in electronic learning (e.g., computers) (Almekhlafi \& Almeqdadi, 2010). Moving beyond the Gulf region, the governments of the KSA and UAE have provided financial and ideological support to Pakistan in shaping its educational infrastructure (Khan, 2018). All of these initiatives can impact students' learning and academic performance (Barber et al., 2007).

In addition, as part of the Gulf States' respective national vision programs on human capital development (Barnett, 2015; Nurunnabi, 2017), schools are emphasizing science, technology, engineering, and mathematics (STEM) education as part of their curriculum, especially as a prerequisite for higher education (Ahmad, Vig \& Dhingra, 2012). In this regard, educational policymakers in the Gulf region have emphasized the importance of the quality of teachers' education in order to make a difference in students' learning outcomes. Well-educated teachers are also necessary to enable assessment at an international standardized achievement level, including the Trends in International Mathematics and Science Study (TIMSS) and the Programme for International Student 


\section{Contribution to the literature}

- The trans-national research study investigated science teachers' self-efficacy beliefs in the educational contexts of Pakistan, Saudi Arabia, and the United Arab Emirates.

- The study highlights the impact of various demographic variables on teachers' personal science efficacy beliefs and science teaching outcome expectancy.

- The study proposes suggestions for improving science teachers' efficacy beliefs in the context of strengthening students' performance in the Islamic region.

Assessment (PISA) (Areepattamannil, 2012; OECD, 2017). TIMSS and PISA are comprehensive global testing bodies that seek to assess students' achievement in the areas of science and mathematics and precisely classify its determinants (Shi et al., 2015). Interestingly, Pakistan's recent entry into the TIMSS 2019 cycle (NCES, 2019) indicates its preparedness to utilize the outcomes from this international standardized testing program as a quality indicator for its education sector. Educators, policymakers, and parents in these three countries are concerned with students' attainment, which is often judged from the perspective of teachers' competencies and their ability to deliver effective instruction (in science education) in accordance with the framework of national priorities.

Despite these initiatives, governments, teacher educators, and educational scholars have expressed serious concern about the performance of students in the public education sector. More seriously, in the KSA, TIMSS data has shown that the average achievement in mathematics for eighth grade students increases with student absenteeism due to the prevalence of private tutoring. Typically, in Gulf Cooperation Council (GCC) countries, parents hire their children's teachers (as tutors) to ensure that the students get high grades though out-of-school "academic preparation." Many teachers do not do their job satisfactorily in order to force parents to hire them as private tutors, which boosts the teachers' generally low income with bonuses and favors from wealthy and influential parents (Faour, 2012).

This concern has led to apprehension over the state of science education in the Gulf States. A GCC Education Sector report stated that "students' achievement in assessments like PISA and TIMSS indicate the performance of the public schools operating in the GCC as a concern of policy makers and administrators" (Ahmad et al. 2012, p. 44).

Similar concerns exist in other global contexts. Over recent decades, the Asian countries of Korea, China, Singapore, Hong Kong, and Malaysia have been reforming their education systems with varying degrees of success, but have faced implementation challenges such as comparing their students' assessment at the international level in science, mathematics, and numeracy. Nevertheless, these countries have been determined to have established strong educational systems that are best fitted for the future (Nisar, 2019).
Pakistan is a South Asian country that is lagging behind in terms of science education. It is facing challenges in its adoption of inquiry- and curiositybased curricula (Nayyar, 2016). This ongoing science education situation is a call for Pakistani policymakers to both revamp science curricula and train teachers to teach science subjects according to contemporary needs. As a non-participating country in international standardized testing, Pakistan's teachers are as motivated for their students to succeed as are their KSA and UAE colleagues, who do participate in PISA and TIMSS.

In order to bring about change in the current state of education, teachers need to question themselves and their beliefs about their prowess as a science educator prior to enhancing students' achievement scores. Research studies report that teachers' beliefs can influence both their teaching and classroom practices (Fang, 1996; Kagan, 1992). Empirical evidence affirms a positive relation between the level of science teaching self-efficacy beliefs and effective science teaching practices (Brand \& Wilkins, 2007).

This research provides more insights by focusing on the significance of teacher efficacy and science education in reference to the cultural differences in Islamic emerging countries, specifically the KSA, UAE, and Pakistan. The aims of this study are to: (1) examine inservice teachers' science efficacy beliefs across these three countries; and (2) investigate the impact of select demographic variables on teachers' personal science efficacy beliefs and science teaching outcome expectancy.

As stated earlier in this article, the Islamic nations (particularly those in the Arabian Gulf region) are focusing on the development of learners' competencies in STEM disciplines; therefore, mapping out the cultural differences in science teaching and teachers' efficacy beliefs in the KSA, the UAE, and Pakistan would further help to investigate these dynamics empirically.

\section{Science Education in KSA}

Until recently, like its Arabian Gulf neighbors, Saudi Arabia used conventional methods of teaching, and the learning materials were not oriented toward students' active engagement (Alhammad, 2015). Alhomairi (2018) reported that the nature of the science curriculum and the design of textbooks in the KSA pose challenges. The revised curriculum is intended to enhance students' 
national identity along with their moral, social, and selfawareness; and to incorporate inquiry-oriented instruction methods. Nonetheless, the KSA's Vision for 2030 aims to provide innovative learning experiences to learners and support teachers with opportunities for professional development.

\section{Science Education in Pakistan}

Pakistan is facing problems in science education, which include: shortage of adequately trained science teachers, poor-quality curriculum material, lack of laboratory facilities that facilitate science teaching, and assessment practices that encourage students' rote learning. Teaching science at different grade levels in Pakistan-as elsewhere-involves different levels of specialization. Consequently, primary level teachers, with their limited academic background, have difficulty teaching elementary level science effectively. Not astonishingly, Pakistan primary school teachers often lack self-confidence about teaching science. Their teaching is at best textbook-based (Halai, 2008).

\section{Science Education in UAE}

While describing the status of science teaching in the UAE, Forawi (2015) listed several issues: (i) the impact of cultural identity on the educational system; (ii) lower levels of (UAE national) students' attitude toward STEM courses; (iii) heterogeneous levels of science learners' English proficiency among public and private schools; and (iv) teachers' professional development and requirement of a license to continue in the profession. Another study by McKinnon, Moussa-Inaty, and Barza (2014) reported that teachers' lack of expertise - in terms of both content and pedagogical knowledge-remained as a challenge to both public and private institutions.

\section{Teacher Self-Efficacy}

There has been growing interest among science education researchers on the influence of teachers' selfefficacy beliefs on their professional career (Hechter, 2011). The psychosocial concept of self-efficacy (i.e., belief in one's ability to succeed) can be employed to determine the relationship between an individual's beliefs and their instructional pedagogy (Bandura, 1977). Bandura noted that individuals are encouraged to act if the action is supposed to provoke a favorable outcome, which he called outcome expectation. Furthermore, Bandura (1977) stated that self-efficacy is a key driver of teachers' behavior and is orchestrated by their affective constructs such as attitude, interest, and beliefs. Selfefficacy beliefs influence thought patterns and emotions, which in turn enable or inhibit actions (Gavora, 2010). Self-efficacy is a derivative of teachers' actual experiences (i.e., mastery experiences), their observation of others (i.e., vicarious experiences), and their social persuasion in a disciplinary area (Bandura, 1993).
The concept of self-efficacy belief in science teaching can be viewed as teachers' belief in their ability to teach science with innovative techniques, leading to an increase in students' academic achievement (Aurah \& McConnell, 2014; Webb-Williams, 2018). Teachers' attitudes and self-efficacy beliefs play an important role in their ability to comprehend classroom strategies and conduct suitable instructional activities (informed by pedagogies) to develop effective thinking patterns in students (Shaukat, 2011). A teacher with a positive attitude and enthusiasm toward science can make a significant difference in students' science learning (Hudson et al., 2010). A teacher with a high sense of efficacy tends to think in more innovative ways when executing classroom tasks and demonstrates a persistent attitude in bringing about change in students' learning, even when facing obstacles to teaching (Cantrell, 2003).

\section{International Research on Teacher Self-Efficacy}

International research on this topic mostly focuses on ways to improve science teaching in primary schools in order to increase students' interest and engagement (McKinnon et al., 2014; Osborne \& Dillon, 2008; Palmer, 2007). Little research examines how different cultures might change the construct of teacher efficacy beliefs (Ferguson 2011; Settlage, Southerland, Smith, \& Ceglie, 2009). Cakironglu (2008) and Lin, Gorrell, and Taylor (2002) undertook a cultural comparison of teachers' efficacy beliefs; both research groups concluded that teachers in diverse cultural contexts may differ in the degree to which they believe themselves to be effective in their teaching. The trans-national study presented in the present research addresses this gap by using a sample frame from three emerging Islamic nations (KSA, UAE, and Pakistan). To support this line of thought, the literature review now turns to scholarship on science teachers' self-efficacy in the international context.

Research has documented the impact of demographic variables on the efficacy beliefs of teachers. Aurah and McConnell (2014) examined American and Kenyan preservice elementary teachers' efficacy beliefs and found a relationship between teacher efficacy beliefs and demographic variables, including country and gender. Alwaleedi (2016) examined the impact of demographic variables on Saudi Arabian in-service teachers' efficacy beliefs in terms of locus of control, persistent behavior, anxiety beliefs, and professional mastery beliefs. The results showed significant differences along all four variables between the self-efficacy beliefs of male and female teachers, teachers with different academic qualifications, primary and secondary teachers, and public and private sector teachers. Gender has been a significant aspect of self-efficacy beliefs; for example, Betz and Hackett (1997) proposed that diverse background experiences associated with gender-role socialization might have led to gender differences in selfefficacy beliefs and self-confidence in respect to precise 
areas of career behavior. Welch and Lawrenz (1982) found that female teachers showed higher scores on measures of concern in science and receptivity to variation, while males showed higher scores on science understanding gauges and on their insights of the teaching support they expected. Kahvechi, Kahvechi, Mansour, and Alarfaj (2018) investigated 994 science teachers from Saudi Arabia and reported that teachers' characteristics such as age and attendance at professional development have an impact on their selfefficacy beliefs about implementing teaching reforms.

Wenner (2001) examined the differences between American pre-service and in-service teachers' mathematics and science teaching efficacy, and found that $58 \%$ of pre-service and $71 \%$ of in-service teachers reported that they could successfully teach science subjects within their classrooms. Those with more experience reported higher science self-efficacy. Conversely, Azhar (2010) investigated Turkish preservice and in-service secondary teachers' science efficacy beliefs, and found that neither gender nor length of teaching experience played a significant role.

Brady et al. (2008) examined Taiwan-based primary teachers' science teaching efficacy and found that teachers with longer teaching experience showed significantly higher teaching efficacy on both subscales of science efficacy: personal science teaching efficacy and science teaching outcome expectancy. Similarly, in a study that focused on Singaporean elementary teachers, Wilson and Tan (2004) reported that the length of professional experience positively influences teachers' self-efficacy beliefs. De la Torre Cruz and Arias (2007) compared Spanish pre-service and in-service teachers' efficacy beliefs, and found that in-service teachers held stronger self-efficacy beliefs than prospective teachers. Campbell (1996) reported similar findings while examining the self-efficacy beliefs of pre-service and inservice teachers in the United States and Scotland.

In summary, the collective outcomes of these studies indicate that in-service teachers with longer teaching experience can develop stronger self-efficacy beliefs in comparison with prospective teachers with less teaching experience. That being said, Desouza et al. (2004) reported that Indian teachers' self-efficacy beliefs were not correlated to their length of professional experience. Their results affirmed that experienced teachers had the lowest levels of self-efficacy beliefs. Karimvand (2011) measured the relationship between the self-efficacy and the teaching experience of Iranian teachers, and concluded that a realistic understanding of how these two constructs are interlinked is not forthcoming. Similarly, McKinnon et al. (2014) reported no clear correlation. However, when these researchers extended the scope of their study to include cultural context and classroom environment, they found that teachers' beliefs and their capability to teach students within a diverse cultural environment influenced their teaching efficacy beliefs.

\section{Teacher Self-efficacy Research in the Arab World}

Research studies related to in-service science teachers' self-efficacy beliefs in the Arab world are mostly specific to the individual educational context of nations belonging to the GCC; that is, they are not comparative in nature, unlike our study. For example, McKinnon et al. (2013) compared teachers' ways of teaching science in private and government schools in the UAE. They reported that teachers in private schools were more inclined to say that they enjoyed teaching science, which can indicate teacher efficacy.

In another study on the science teaching self-efficacy of culturally foreign teachers in the UAE, McKinnon et al. (2014) reported a much lower sense of self-efficacy compared with other studies using the Science Teaching Efficacy Belief Instrument (STEBI) (see Enoch \& Riggs, 1990). McKinnon et al. concluded that cultural adaptation (both personal and professional) may influence science teachers' self-efficacy. In summary, this literature review affirms that there is a scarcity of research on the comparison of science teachers' selfefficacy beliefs among the Gulf and/or emerging Islamic nations. This benchmark study involving in-service science teachers from the KSA, Pakistan, and the UAE enables respective educational leaders, policymakers, and authorities to understand the relative strengths and weaknesses of their educational systems and make educational policy changes accordingly.

\section{Research Questions}

The purpose of this research was to determine inservice teachers' science self-efficacy beliefs across three emergent Islamic countries. It was guided by two questions:

1. What are the science self efficacy beliefs of inservice teachers in the KSA, Pakistan, and the UAE?

2. Is there any level of interaction between the selfefficacy beliefs, background qualification, and level of teaching experience of in-service teachers in the KSA, Pakistan, and the UAE?

\section{MATERIALS AND METHODS}

This study underpins the theoretical frameworks of Bandura (1993) and Enoch and Riggs (1990) on science teachers' self-efficacy beliefs and their relevance to their performance as practitioners - particularly in collectivist cultural contexts such as the KSA, Pakistan, and the UAE. Utilizing this theoretical lens, the proposed research questions may provide further opportunities to examine the collected data to verify any directly or indirectly identifiable evidence in support of teachers' performance in the chosen educational contexts. This 
Table 1. Summary of Demographic Variables. Values given are number of participants ( $n$ ). Percentage values (rounded to nearest whole number) are shown in parentheses

\begin{tabular}{|c|c|c|c|c|c|c|c|c|c|c|c|c|c|c|c|}
\hline & \multicolumn{2}{|c|}{ Gender } & Age & \multicolumn{2}{|c|}{$\begin{array}{c}\text { Teaching } \\
\text { Experience }\end{array}$} & \multicolumn{2}{|c|}{$\begin{array}{c}\text { Teaching } \\
\text { Level }\end{array}$} & \multicolumn{2}{|c|}{$\begin{array}{c}\text { Nature } \\
\text { of School }\end{array}$} & \multicolumn{6}{|c|}{ Qualifications } \\
\hline & Male & Female & $\leq 30 \geq 30$ & $\leq 10$ & $\geq 10$ & Ele. & Sec. & Public & Private & $\begin{array}{c}\text { Bachelor's } \\
\text { degree in } \\
\text { Science }\end{array}$ & $\begin{array}{c}\text { Master's } \\
\text { degree in } \\
\text { Science }\end{array}$ & $\begin{array}{l}\text { Bachelor } \\
\text { in } \\
\text { Education }\end{array}$ & $\begin{array}{l}\text { Bachelor } \\
\text { in } \\
\text { Sci. Edu. }\end{array}$ & $\begin{array}{l}\text { Master } \\
\text { in } \\
\text { Sci. Edu. }\end{array}$ & Other \\
\hline Saudi & 33 & 193 & 60166 & 115 & 111 & 75 & 151 & 134 & 92 & 100 & 5 & 14 & 91 & 6 & 10 \\
\hline Arabia & (15) & (85) & (27) (74) & (51) & (49) & (33) & (67) & (59) & (41) & $(44)$ & $(2)$ & (6) & $(40)$ & (3) & (4) \\
\hline Pakistan & $\begin{array}{c}44 \\
(34)\end{array}$ & $\begin{array}{l}86 \\
(66)\end{array}$ & $\begin{array}{cc}94 & 36 \\
(72) & (28)\end{array}$ & $\begin{array}{l}107 \\
(82)\end{array}$ & $\begin{array}{c}23 \\
(18)\end{array}$ & $\begin{array}{l}58 \\
(45)\end{array}$ & $\begin{array}{c}72 \\
(55)\end{array}$ & $\begin{array}{c}75 \\
(58)\end{array}$ & $\begin{array}{c}55 \\
(42)\end{array}$ & $\begin{array}{c}20 \\
(15)\end{array}$ & $\begin{array}{c}54 \\
(42)\end{array}$ & $\begin{array}{l}16 \\
(12)\end{array}$ & $\begin{array}{c}2 \\
(2)\end{array}$ & $\begin{array}{l}7 \\
(5)\end{array}$ & $\begin{array}{c}31 \\
(24)\end{array}$ \\
\hline UAE & $\begin{array}{c}26 \\
(26)\end{array}$ & $\begin{array}{l}73 \\
(74)\end{array}$ & $\begin{array}{cc}31 & 68 \\
(31) & (69)\end{array}$ & $\begin{array}{c}54 \\
(55)\end{array}$ & $\begin{array}{c}45 \\
(46)\end{array}$ & $\begin{array}{c}41 \\
(41)\end{array}$ & $\begin{array}{c}58 \\
(59)\end{array}$ & $\begin{array}{l}15 \\
(15)\end{array}$ & $\begin{array}{c}84 \\
(85)\end{array}$ & $\begin{array}{c}51 \\
(52)\end{array}$ & $\begin{array}{c}23 \\
(23)\end{array}$ & $\begin{array}{l}7 \\
(7)\end{array}$ & $\begin{array}{c}8 \\
8 \\
(8)\end{array}$ & $\begin{array}{c}4 \\
(4)\end{array}$ & $\begin{array}{c}6 \\
(6)\end{array}$ \\
\hline Total & $\begin{array}{l}103 \\
(23)\end{array}$ & $\begin{array}{l}352 \\
(77)\end{array}$ & $\begin{array}{ll}185 & 270 \\
(41) & (59)\end{array}$ & $\begin{array}{l}276 \\
(61)\end{array}$ & $\begin{array}{l}179 \\
(39)\end{array}$ & $\begin{array}{l}174 \\
(38)\end{array}$ & $\begin{array}{l}281 \\
(62)\end{array}$ & $\begin{array}{l}225 \\
(50)\end{array}$ & $\begin{array}{l}231 \\
(51)\end{array}$ & $\begin{array}{l}171 \\
(38)\end{array}$ & $\begin{array}{c}82 \\
(18)\end{array}$ & $\begin{array}{l}37 \\
(8)\end{array}$ & $\begin{array}{l}101 \\
(22)\end{array}$ & $\begin{array}{l}17 \\
(4)\end{array}$ & $\begin{array}{l}47 \\
(10)\end{array}$ \\
\hline
\end{tabular}

quantitative study employs a cross-sectional survey research design (Creswell, 2007). Once ethical permission was received from the three respective universities' Institutional Review Boards (IRBs) (in the KSA, Pakistan, and the UAE), the research was conducted during 2017-2018.

\section{Sampling}

The researchers used purposive sampling to recruit in-service teachers from both primary and secondary urban schools who were teaching a broad range of science subjects (i.e., general science at the primary level and natural sciences such as biology and chemistry at the secondary level). The sample frame comprised five schools per country and included both private and public schools. The researchers obtained necessary permissions to administer the survey. Approximately 600 teachers (across three countries) were approached during the data collection phase. The final sample comprised 455 respondents (78\% response rate) from the KSA $(n=226 ; 50 \%)$, Pakistan $(n=130 ; 29 \%)$, and the UAE $(n=99 ; 22 \%)$. The Saudi Arabian cohort belonged to five major schools from Dammam region. These teachers had consented to participate in the study while attending a professional development program, organized by one of the authors - on science teaching competencies. The participants were assured that their participation was voluntary, they could withdraw at any stage without penalty, and their identity would remain anonymous.

The General Demographic Survey variables, as shown in Table 1, revealed that the majority of the respondents were female $(n=352 ; 77 \%)$, with a lower proportion of male respondents $(n=103 ; 23 \%)$. The majority of the respondents were 30 years or older $(n=$ $270 ; 59 \%)$, with a smaller proportion aged less than 30 years $(n=185 ; 41 \%)$. Nearly two thirds of the respondents had less than 10 years of professional experience $(n=276 ; 61 \%)$, while more than one third $(n$ $=179 ; 39 \%$ ) had more than 10 years. The respondents represented mainly secondary school teachers $(n=281$; $62 \%)$, followed by elementary school teachers $(n=174$; $38 \%)$, split evenly according to the private $(n=230 ; 51 \%)$ and public $(n=225 ; 49 \%)$ sectors.
Regarding academic qualifications, the majority of respondents ( $n=171 ; 38 \%)$ held a Bachelor's degree in science. Other qualifications (52\%) included, in descending order: a Bachelor's degree in science education $(n=101)$; a Master's degree in science $(n=82)$; a Bachelor's degree in education $(n=37)$, and a Master's degree in science education $(n=17)$. In effect, most respondents $(68 \%)$ held bachelor-level degrees, followed by master-level $(22 \%)$ qualifications. The remaining teachers $(n=47 ; 10 \%)$ possessed other types of qualifications or training, such as short training programs.

\section{INSTRUMENTS}

The instrument used in this research comprised two sections: Part 1-General Demographic Survey; and Part 2-Science Teaching Efficacy Beliefs Instrument (STEBIB) (Enochs \& Riggs, 1990).

\section{Part 1: General Demographic Survey}

A general column requested teachers to provide basic demographic background information such as nationality, gender, age, number of years teaching experience, and academic qualifications.

\section{Part 2: Science Teaching Efficacy Beliefs Instrument}

To measure teachers' self-efficacy beliefs, the STEBIB scale developed by Enochs and Riggs (1990) was utilized. The original STEBI is a 25 item five-point Likerttype instrument containing two subscales: Personal Science Teaching Efficacy Beliefs (13 items) and Science Teaching Outcome Expectancy (12 items). The items in Personal Science Teaching Efficacy Beliefs collectively indicate teachers' beliefs about their own ability to be an effective teacher. The items in Science Teaching Outcome Expectancy refer to teachers' beliefs about whether students can learn if effective teaching takes place (Haney et al., 2007). These two subscales represent the relationship of the instrument to Bandura's (1997) two-factor concept of efficacy: efficacy-expectation and outcome-expectancy (Bleicher, 2004). 
Table 2. Descriptive Statistics and Results of the One-Way ANOVA

\begin{tabular}{|c|c|c|c|c|c|c|c|c|c|c|c|}
\hline \multirow{2}{*}{$\begin{array}{l}\text { STEBI } \\
\text { subscale }\end{array}$} & \multicolumn{2}{|c|}{$\begin{array}{c}\text { Saudi Arabia } \\
(n=226)\end{array}$} & \multicolumn{2}{|c|}{$\begin{array}{l}\text { Pakistan } \\
(n=130)\end{array}$} & \multicolumn{2}{|c|}{$\begin{array}{c}\text { UAE } \\
(n=99)\end{array}$} & \multicolumn{2}{|c|}{$\begin{array}{c}\text { Total } \\
(n=455)\end{array}$} & \multirow[t]{2}{*}{$d f$} & \multirow[t]{2}{*}{ F } & \multirow{2}{*}{$\begin{array}{c}\text { Sig. } \\
(p<0.0001)\end{array}$} \\
\hline & Mean & SD & Mean & SD & Mean & SD & Mean & SD & & & \\
\hline$\overline{\text { PSTE }}$ & 3.34 & 0.38 & 3.29 & 0.46 & 3.07 & 0.43 & 3.27 & 0.43 & 2 & 15.600 & .0001 \\
\hline STOE & 3.72 & 0.48 & 3.97 & 0.43 & 3.85 & 0.37 & 3.82 & 0.46 & 2 & 13.502 & .0001 \\
\hline
\end{tabular}

The STEBI-B scale used in this study is a validated tool in the American context, particularly in regard to science teaching. Although STEBI-B is recommended for pre-service teachers, it can be used with in-service teachers as well (Enochs \& Riggs, 1990). This scale is also based on a five-point Likert-type classification, with responses that include Strongly Disagree (1), Disagree (2), Not Sure (3), Agree (4), and Strongly Agree (5). Examples of the subscales are as follows: "If students are underachieving in science, it is most likely due to ineffective science teaching" (from the STOE subscale) and "I know the steps necessary to teach science concepts effectively" (from the PSTE subscale).

For this study, the 25 items were adapted and the negatively scored items were reverse-coded. Enochs and Riggs (1990) reported the Cronbach's alpha coefficients as 0.90 and 0.76 for PSTE and STOE, respectively. For the current study, the Cronbach's alpha was 0.72 for PSTE and 0.64 for STOE. These were deemed satisfactory (George \& Mallery, 2003) according to the number of items in both subscales. Indeed, while administering the same scale in the UAE context, McKinnon et al. (2014) obtained 0.86 for PSTE and 0.60 for STOE.

\section{Data Collection Procedure}

Data were collected in the three countries within a three-month timeframe (May 2018-July 2018), taking an average of one week for each country. On average, five schools were involved in each country, including both public and private schools. A drop-off/pick-up (DOPU) survey method was used (Jackson-Smith et al., 2016). The instrument was administered in person, and respondents completed the survey in 15-20 minutes. The average response rate was $78 \%$ (differing within countries). This response rate was higher than the $64 \%$ rate expected with the DOPU approach (Jackson-Smith et al., 2016), thus negating the need for follow-up. Each researcher analyzed the dataset for his or her respective country. The three datasets were each analyzed using descriptive statistics, a one-way analysis of variance (ANOVA), and a two-way multivariate analysis of variance (MANOVA).

\section{RESULTS AND DISCUSSION}

\section{Research Question 1}

The first research question was concerned with measuring the science efficacy beliefs of in-service teachers in the KSA, Pakistan, and the UAE. Descriptive statistics (mean scores) were used to answer this question (see Tables 2, 3a, and 3b). Table 2 shows the mean scores of the total participants for each country, whereas Tables $3 \mathrm{a}$ and $3 \mathrm{~b}$ show gender-wise mean scores. Teachers' responses to the two STEBI-B subscales were computed. Respondents' mean scores for PSTE and STOE were found to be marginal across the three countries. Furthermore, results from a one-way ANOVA show significant differences among the science teachers' perceptions of their self-efficacy beliefs across the KSA, Pakistan, and the UAE (see Table 2).

The UAE teachers reported lower levels (3.07) of personal science teaching efficacy beliefs; their scores for items 19, 20, 21, and 23 were the lowest in comparison with those from the KSA and Pakistan. On the other hand, the Saudi teachers' score (3.72) for science teaching outcome expectancy reflected their lower rating for items 7, 14, and 15 in comparison with those from Pakistan and the UAE.

Male and female teachers' responses to the STEBI-B subscales are presented in Table $3 a$. Both male and female UAE teachers scored lower on personal science efficacy beliefs and science teaching outcome expectancy than their KSA and Pakistani counterparts. Pakistani teachers' science teaching outcome expectancy (3.97) was higher than their KSA (3.72) and UAE colleagues (3.85). Gender differences were not significant within specific nations, but did manifest when comparing one nation with another.

A two-way MANOVA was also performed to determine gender differences among teachers from the KSA, Pakistan, and the UAE (Table 3b). The two dependent variables included personal science teaching efficacy beliefs and science teaching outcome expectancy (i.e., the subscales). The two independent variables were gender and nationality. Preliminary assumption testing was conducted to check for normality, linearity, univariate and multivariate outliers, homogeneity of variance-covariance matrices, and multi-collinearity, with no serious violations noted. Table $3 b$ reveals statistically significant differences among teachers from the three countries on both subscales. Similarly, there were statistically significant gender differences among teachers in their science efficacy beliefs. In contrast, the interaction of gender and nationality showed no statistically significant differences for both subscales.

\section{Research Question 2}

The second research question was concerned with the interaction level between self-efficacy beliefs, 
Table 3a. Gender Differences in In-Service Science Teachers' Self-Efficacy Beliefs

\begin{tabular}{|c|c|c|c|c|c|c|c|c|c|c|c|c|}
\hline \multirow{3}{*}{ STEBI subscale } & \multicolumn{4}{|c|}{ Saudi Arabia } & \multicolumn{4}{|c|}{ Pakistan } & \multicolumn{4}{|c|}{ UAE } \\
\hline & \multicolumn{2}{|c|}{$\begin{array}{c}\text { Male } \\
(n=33)\end{array}$} & \multicolumn{2}{|c|}{$\begin{array}{c}\text { Female } \\
(n=193)\end{array}$} & \multicolumn{2}{|c|}{$\begin{array}{c}\text { Male } \\
(n=44)\end{array}$} & \multicolumn{2}{|c|}{$\begin{array}{l}\text { Female } \\
(n=86)\end{array}$} & \multicolumn{2}{|c|}{$\begin{array}{c}\text { Male } \\
(n=26)\end{array}$} & \multicolumn{2}{|c|}{$\begin{array}{l}\text { Female } \\
(n=73)\end{array}$} \\
\hline & Mean & SD & Mean & SD & Mean & SD & Mean & SD & Mean & SD & Mean & SD \\
\hline Personal science teaching efficacy beliefs & 3.28 & 0.33 & 3.36 & 0.39 & 3.16 & 0.50 & 3.36 & 0.43 & 3.04 & 0.52 & 3.07 & 0.40 \\
\hline Science teaching outcome expectancy & 3.58 & 0.48 & 3.75 & 0.48 & 4.00 & 0.46 & 3.96 & 0.42 & 3.81 & 0.40 & 3.86 & 0.36 \\
\hline
\end{tabular}

Table 3b. Two-way MANOVA for Gender and Country Differences in Each Subscale of STEBI

\begin{tabular}{ccccccc}
\hline \multirow{2}{*}{ STEBI subscale } & \multicolumn{2}{c}{ Gender } & \multicolumn{2}{c}{ Country } & \multicolumn{2}{c}{ Gender ${ }^{*}$ country } \\
\cline { 2 - 7 } & $\boldsymbol{F}$ & Eta $^{2}$ & $\boldsymbol{F}$ & Eta $^{2}$ & $\boldsymbol{F}$ & Eta $^{2}$ \\
\hline Personal science teaching efficacy beliefs & $4.64^{*}$ & 0.01 & $9.38^{* *}$ & 0.04 & 1.00 & 0.00 \\
Science teaching outcome expectancy & 1.39 & 0.00 & $14.56^{* *}$ & 0.06 & 1.49 & 0.01 \\
\hline
\end{tabular}
${ }^{* *} p<.001 ;{ }^{*} p<.05$

Table 4. Two-way MANOVA for qualification levels and experience differences in each STEBI-B subscale for teachers from the KSA, Pakistan, and the UAE

\begin{tabular}{cccccccc}
\hline \multirow{2}{*}{ Sample } & \multirow{2}{*}{ STEBI subscale } & \multicolumn{2}{c}{ Qualification } & \multicolumn{2}{c}{ Experience } & \multicolumn{2}{c}{ Qualification $\times$ experience } \\
\cline { 3 - 8 } & & $\boldsymbol{F}$ & Eta $^{2}$ & $\boldsymbol{F}$ & Eta $^{2}$ & \multicolumn{1}{c}{ Eta $^{2}$} \\
\hline \multirow{2}{*}{ KSA, Pakistan, and } & PSTE & $2.24^{*}$ & 0.02 & 0.34 & 0.00 & $5.01^{* *}$ & 0.05 \\
UAE & STOE & $4.72^{* *}$ & 0.05 & 0.36 & 0.00 & 1.82 & 0.02 \\
\hline \multirow{2}{*}{ KSA } & PSTE & $2.87^{* * *}$ & 0.06 & 0.31 & 0.00 & 1.38 & 0.03 \\
& STOE & $2.79^{* * *}$ & 0.06 & 0.70 & 0.00 & 1.02 & 0.02 \\
\hline \multirow{2}{*}{ Pakistan } & PSTE & 1.71 & 0.07 & 0.03 & 0.00 & 1.50 & 0.05 \\
& STOE & 0.57 & 0.02 & $3.30^{*}$ & 0.03 & 1.57 & 0.05 \\
\hline \multirow{2}{*}{ UAE } & PSTE & 1.34 & 0.07 & 1.09 & 0.01 & $2.64^{* * *}$ & 0.13 \\
& STOE & 0.93 & 0.05 & $5.31^{* * *}$ & 0.06 & $2.41^{* * *}$ & 0.12 \\
\hline
\end{tabular}

${ }^{* *} p<.005 ;{ }^{*} p<.01 ;{ }^{* * *} p<.05$

background qualification, and teaching experience level of in-service science teachers in the KSA, Pakistan, and the UAE. A two-way MANOVA was used to address this question. The results (Table 4 ) for the interaction of qualifications and experience seemed to indicate that, these factors played an important role in teachers' efficacy beliefs. The educational qualifications of the teachers from all three regions appeared to have an impact on their perceptions of efficacy beliefs and outcome expectancy. The teachers' professional experience did not seem to have an impact on the two subscales. Only the KSA teachers showed statistically significant differences in their perceptions of efficacy beliefs and outcome expectancy.

The importance of the impact of educational qualifications and professional experience on teachers' selfefficacy beliefs was evaluated using effect size statistic (see Table 4 for partial eta squared values). The partial eta squared values represent the proportion of variance in teachers' self-efficacy beliefs that can be explained by their educational qualifications and professional experience. Cohen's (1988) recommended effect size range was used: small (0.019), medium (0.06), and large (0.14). The partial eta squared values of PSTE (0.05) and STOE (0.02) for all three countries are considered to show a small to medium effect. For UAE teachers, the partial eta squared values for PSTE (0.13) and STOE (0.12) show a medium to large effect.

\section{DISCUSSION}

The issues driving this study were: (1) concerns regarding GCC student performance on PISA and TIMSS, and (2) the lack of comparative data for GCC nations pursuant to science teachers' self-efficacy (Ahmad et al., 2012; Areepattamannil, 2012). With this data, emergent Islamic countries can better understand the contextual nuances of science teaching in their respective country. This is important because the level of teacher self-efficacy when teaching science affects their science teaching practices (Brand \& Wilkins, 2007; Gavora, 2010), which affects students' academic success (Aurah \& McConnell, 2014; Hudson et al., 2010).

The results from administering the STEBI-B (Enochs \& Riggs, 1990) showed significant differences in the PSTE and STOE of teachers in the KSA, Pakistan, and the UAE. The results obtained in this study are consistent with previous studies on cultural comparisons of science teacher efficacy; for example, Aurah and McConnell (2014) and Lin et al. (2002) also found that science teachers' self-efficacy varied by country.

\section{Country Differences}

In more detail, the KSA teachers had stronger personal science teaching efficacy, while Pakistani science teachers seemed to have strong science teaching outcome expectation efficacy. That is, KSA teachers were confident in their own teaching while Pakistani teachers 
were confident that their students were learning because of their teaching. This finding is interesting because Pakistan does not participate in PISA or TIMSS. Although Pakistani teachers are motivated for their students to succeed, the nation is lagging behind in science education (Nayyar, 2016). Our results for Pakistan are encouraging because teachers acting with a high sense of efficacy can bring about student success despite challenges to teaching (Cantrell, 2003).

Although the mean differences among countries regarding the level of science efficacy were marginal (see Table 2), the effect size (i.e., magnitude of the difference, Eta squared values, as shown in Table 4) may suggest that teachers from these three countries tend to differ in their science efficacy (see Aurah \& McConnell, 2014; Lin et al., 2002). As Bandura (1993) asserted, it is one thing to have knowledge and skills and another thing to be able to utilize them well and perceive that one does so. Our results suggest that teachers from different countries who practice with similar skills and knowledge may have varying levels of a sense of self-efficacy. These results mean that educational institutions in different GCC countries should not rely on generic science preservice teacher preparation curricula. Efficacy levels varied from the KSA to Pakistan and the UAE. In order to achieve and build confidence in pre-service science teachers in these different countries, it will be necessary to tailor the curricula to accommodate cultural nuances. GCC curriculum planners can learn from each other (Nisar, 2019).

\section{Teaching Experience and Academic Qualifications}

Teaching experience grants teachers a stable sense of their ability to manage the new teaching challenges they may face in variable situations. Experienced teachers tend to teach science content to their students in a more extensive way, as their long career provides opportunities to gain mastery over the content and its instructional delivery. In our study, academic qualifications and years of experience played a significant role in influencing the efficacy beliefs and STOE of (see Table 4) KSA teachers. Similarly, other researchers have asserted that teacher efficacy and teaching experience have a strong correlation; teaching experience improves teacher efficacy (Brady et al., 2008; de la Torre Cruz \& Arias, 2007; Desouza et al., 2004; Ross, 1998; Wenner, 2001; Wilson \& Tan, 2004).

The lack of significant results for the UAE and Pakistan may reflect other researchers' assertions that the correlation between qualifications, years of experience, and efficacy is not clearly established yet (Karimvand, 2011; McKinnon et al., 2014). Clearly, this result merits further investigation, especially in regards to the age of the teaching population in each GCC nation. It also raises the possibility that it is unrealistic to expect newly minted teachers to be immediately effective in raising GCC students' scores on international tests. Their self-efficacy as science teachers will have to be nurtured and supported through contextually specific professional development (PD).

\section{Gender Differences and Cultural Impact}

Gender differences in self-efficacy beliefs were not found to be statistically significant within specific nations, but did manifest when comparing one nation with another. Regarding the former, the lack of gender difference in self-efficacy found within countries contradicts Alwaleedi's (2016) finding that gender affected self-efficacy. Regarding differences among nations, our results confirmed that the personal science efficacy beliefs of male (3.01) and female teachers (3.07) in the UAE were lower than those of their KSA (3.38; $3.26)$ and Pakistani $(3.16 ; 3.36)$ counterparts. This means that UAE teachers scored the lowest on beliefs about their own ability to be an effective science teacher (see also Haney et al., 2007). This ability pertains to owning intrinsic characteristics and being able to address challenges related to the nature of teaching. Aurah and McConnell (2014) also found an association between teacher efficacy beliefs and gender. In our study, male and female UAE teachers seemed to lack confidence in their ability to effectively know about, understand, and teach science content in classrooms. This finding is concerning, because teachers' beliefs can influence their teaching (Fang, 1996; Kagan, 1992), which can influence students' success.

By way of explanation, the UAE, compared with the KSA and Pakistan, is a culturally diverse country where teachers with different nationalities bring a range of different language styles and cultural outlooks to their teaching experiences; their organismic characteristics and classroom environments influence their confidence to teach curricular content (McKinnon et al., 2013, 2014). Furthermore, the multicultural UAE classroom environment poses yet another challenge to teachers in the UAE with different nationalities, who are in turn teaching students with diversified learning styles. This finding has future implications for the PD and coaching of teachers in UAE who, as shown in our study, have little confidence, while writing up their opinions on the science efficacy survey. McKinnon et al. (2014) concurred that cultural adaptation (especially professional adaptation) in the GCC geographical region may influence science teachers' self-efficacy, and merits further study.

\section{STUDY LIMITATIONS}

It is essential to demonstrate an awareness of science education in these three countries and to examine how they differ. All three countries studied here are Islamic, so the nature of scientific enquiry is "foreign" to the 
culture, and the variants of Islam can confuse the issues even further.

This study has several limitations. First, the relatively small sample size may not represent the views of the majority of teachers from the three countries. Second, in hindsight, reliability and validity concerns may exist due to the cultural differences among the respondents and their understanding of the survey instrument (Dimmock, 2007). Third, future studies are encouraged to augment the quantitative survey data with qualitative research in order to explore the connections between beliefs and actions that might impact teachers' science teaching efficacy and practices. A final limitation is that this study did not address the relationship between science teachers' efficacy beliefs and students' achievements in these three countries. These data would be useful to place science teachers' efficacy beliefs and their actions within the context of students' PISA and TIMSS scores.

\section{CONCLUSIONS}

This is the first trans-national study examining inservice science teachers' self-efficacy beliefs in the educational contexts of emergent Islamic countries (the KSA, Pakistan, and the UAE). The results affirm the need to both revamp pre-service science teacher education programs and redesign in-service PD initiatives. Different countries will likely need different curricula that respect the roles of cultural adaptation, nationality, gender, academic qualifications, and years of teaching experience. Achieving higher levels of science teacher self-efficacy may improve student achievements on international standardized tests such as PISA and TIMSS. Improved science scores for GCC students may contribute to the global reputation, competitiveness, and contributions of the Gulf Arab States. The benchmarked nature of the results paves the way for additional comparative trans-national educational studies focused on the teaching efficacy of GCC science teachers.

\section{REFERENCES}

Ahmad, S., Vig, S., \& Dhingra, L. (2012). GCC Education Sector Report. GFH of Manama, Kingdom of Bahrain: GFH.

Alhammad, K. (2015). A conceptual framework for reshaping science education in Saudi Arabia. In N. Mansour \& S. Al-Shamrani (Eds.), Science Education in the Arab Gulf States (pp. 121-136). Boston, MA: Sense Publishers. https:/ / doi.org/10.1007/978-946300-049-9_6

Almazroa, H., \& Al-Shamrani, S. (2015). Saudi science teacher professional development. In N. Mansour \& S. Al-Shamrani (Eds.), Science Education in the Arab Gulf States (pp. 3-21). Rotterdam, Netherlands:
Sense Publishers. https:/ / doi.org/10.1007/978-946300-049-9_1

Almekhlafi, A. G., \& Almeqdadi, F. A. (2010). Teachers' perceptions of technology integration in the United Arab Emirates school classrooms. Educational Technology \& Society, 13(1), 165-175. Retrieved from https:/ / search-proquest-com.dbgw.lis.curtin.edu. au/docview / 2139127741 ?accountid=10382

Alwaleedi, M. (2016). Impact of demographic variables in the development of teachers' self-efficacy beliefs in the context of Saudi Arabia. Asian Social Sciences, 13(1). https:/ / doi.org/10.5539/ass. v13n1p1

Areepattamannil, S. (2012). Science self-beliefs and science achievement of adolescents in Gulf Cooperation Council countries. Educational Studies, 38(1), 13-17. https://doi.org/10.1080/03055698. 2011.567058

Aurah, C., \& McConnell, T. (2014). Comparative study on pre-service science teachers' self efficacy beliefs of teaching in Kenya and the United States of America. American Journal of Educational Research, 2(4), 233-239. https:// doi.org/10.12691/education2-4-9

Azar, A. (2010). In-service and pre-service secondary science teachers' self-efficacy beliefs about science teaching. Educational Research Review, 5(4), 175-188.

Bandura, A. (1977). Self-efficacy: Toward a unifying theory of behavioral change. Psychological Review, 84(2), 191-215. https://doi.org/10.1037/0033295X.84.2.191

Bandura, A. (1993). Perceived self-efficacy in cognitive development and functioning. Educational Psychologist, 28(2), 117-148. https://doi.org/ 10.1207/s15326985ep2802_3

Bandura, A. (1997). Self-Efficacy: The Exercise of Control. New York, NY: W. H. Freeman and Company.

Barber, M., Mourshed, M., \& Whelan, F. (2007). Improving education in the Gulf. The McKinsey Quarterly, 39-47.

Barnett, C. (2015). Human Capital and the Future of the Gulf. Center for Strategic \& International Studies. New York, NY: Rowman \& Littlefield.

Betz, N. E., \& Hackett, G. (1997). Applications of selfefficacy: Theory to career assessment of women. Journal of Career Assessment, 5(4), 383-402. https:// doi.org/10.1177/106907279700500402

Bleicher, R. E. (2004). Revisiting the STEBI-B: Measuring self-efficacy in preservice elementary teachers. School Science and Mathematics, 104(8), 383-391. https:// doi.org/10.1111/j.19498594.2004.tb18004.x

Brady, M. J., Chia-Ju, L., \& Houn-Lin, C. (2008). Taiwan elementary teachers' views of science teaching selfefficacy and outcome expectations. International 
Journal of Science and Mathematics Education, 6(2), 1935. https:/ / doi.org/10.1007/s10763-006-9065-4

Brand, B. R., \& Wilkins, J. L. M. (2007). Using self-efficacy as a construct for evaluating science and mathematics methods courses. Journal of Science Teacher Education, 18(2), 297-317. https:/ / doi.org/10.1007/s10972-007-9038-7

Cakironglu, E. (2008). The teaching efficacy beliefs of pre-service teachers in the USA and Turkey. Journal of Education for Teaching, 34(1), 33-44. https:/ / doi.org/10.1080/02607470701773457

Campbell, J. (1996). A comparison of teacher efficacy for pre-service and in-service teachers in Scotland and America. Education, 117(1), 2-11.

Cantrell, P. (2003). Traditional vs. retrospective pretests for measuring science teaching efficacy beliefs in preservice teachers. School Science and Mathematics, 103(4), 177-185. https://doi.org/10.1111/j.19498594.2003.tb18116.x

Cohen, J. (1988). Statistical Power Analysis for the Behavioral Sciences (2nd ed.). Mahwah, NJ: Lawrence Erlbaum Associates, Publishers.

Creswell, J. W. (2007). Research Design (3rd ed). Thousand Oaks, CA: Sage Publications.

de la Torre Cruz, M. J., \& Arias, M. J. (2007). Comparative analysis of experiences of efficacy in in-service and prospective teachers. Teaching and Teacher Education, 23(5), 641-652. https:/ / doi.org/10.1016/ j.tate.2007.02.005

Desouza, J. M. S., Boone, W. J., \& Yilmaz, O. (2004). A study of science teaching self-efficacy and outcome expectancy beliefs of teachers in India. Science Education, 88(6), 837-854. https://doi.org/ $10.1002 /$ sce. 20001

Dimmock, C. (2007). Cross-cultural differences in interpreting and conducting research. In A. Briggs \& M. Coleman (Eds.), Research Methods in Educational Leadership and Management ( $2^{\text {nd }}$ ed.) (pp. 53-66). Thousand Oaks, CA: Sage Publications.

Enochs, L. G., \& Riggs, I. M. (1990). Further development of an elementary science teaching efficacy belief instrument: A preservice elementary scale. School Science and Mathematics, 90(8), 694-706. https:/ / doi. org/10.1111/j.1949-8594.1990.tb12048.x

Fang, Z. (1996). A review of research on teacher beliefs and practices. Educational Research, 38(1), 47-65. https:/ / doi.org/10.1080/0013188960380104

Faour, M. (2012). The Arab World's Education Report Card: School Climate and Citizenship Skills. Washington, DC: Carnegie Endowment for International Peace Publications.

Ferguson, M. R. (2011). Finding a home abroad with Eveline: Using narrative inquiry to establish a sense of place for a Western teacher in a foreign and multicultural context. Journal of Studies in International Education, 15(1), 25-40. https:/ / doi.org/10.1177/1028315309337928

Forawi, S. A. (2015). Science teacher professional development needs in the United Arab Emirates. In N. Mansour \& S. Al-Shamrani (Eds.), Science Education in the Arab Gulf States (pp. 49-68). Rotterdam, Netherlands: Sense Publishers. https:/ / doi.org/10.1007/978-94-6300-049-9_3

Gavora, P. (2010). Slovak pre-service teacher selfefficacy: Theoretical and research considerations. New Education Review, 21(2), 17-30.

George, D., \& Mallery, P. (2003). SPSS for Windows Step by Step: A Simple Guide and Reference 11.0 Update $\left(4^{\text {th }}\right.$ ed.). Boston, MA: Allyn \& Bacon.

Halai, N. (2008). Curriculum reform in science education in Pakistan. Science Education in Context: An International Examination of the Influence of Context on Science Curricula Development and Implementation, 115-129. https:// doi.org/10.1163/9789087902490_ 011

Haney, J. J., Wang, J., Keil, C., \& Zoffel, J. (2007). Enhancing teachers' beliefs and practices through problem-based learning focused on pertinent issues of environmental health science. Journal of Environmental Education, 38(4), 25-33. https:// doi.org/10.3200/JOEE.38.4.25-33

Hechter, P. R. (2011). Changes in preservice elementary teachers' personal science teaching efficacy and science teaching outcome expectancies: The influence of context. Journal of Science Teacher Education, 22(2), 187-202. https:/ / doi.org/10.1007/ s10972-010-9199-7

Hudson, P., Usak, M., Fancovicova, J., Erdogan, M., \& Prokop, P. (2010). Preservice teachers' memories of their secondary science education experiences. Journal of Science Education and Technology, 19(6), 546-552. https://doi.org/10.1007/s10956-0109221-Z

Jackson-Smith, D., Flint, C. G., Dolan, M., Trenmtelman, C. K., Holyoak, G., Thomas, B., \& Ma, G. (2016). Effectiveness of the drop-off/pick-up survey methodology in different neighbourhood types. Journal of Rural Social Sciences, 31(3), 35-67. Retrieved from https://search-proquest-com. dbgw.lis.curtin.edu.au/docview/1872116900?acco untid $=10382$

Kagan, D. M. (1992). Implications of research on teacher belief. Educational Psychologist, 27(1), 65-90. https:// doi.org/10.1207/s15326985ep2701_6

Karimvand, P. N. (2011). The nexus between Iranian EFL teachers' self-efficacy, teaching experience and gender. English Language Teaching, 4(3), 71-183. https:// doi.org/10.5539/elt.v4n3p171 
Khan, M. (2018). Economics of UAE-Pakistan bilateral relations. Defence Journal, 21(6), 18-28. Retrieved from https:/ / search-proquest-com.dbgw.lis.curtin. edu.au/docview / 2026958427?accountid=10382

Lin, H., Gorrell, J., \& Taylor, J. (2002). Influence of culture and education on U.S. and Taiwan pre-service teachers' efficacy beliefs. Journal of Educational Research, 96(1), 37-46. https://doi.org/10.1080/ 00220670209598789

McKinnon, M., Barza, L., \& Moussa-Inaty, J. (2013). Public versus private education in primary science: The case of Abu Dhabi primary schools. International Journal of Educational Research, 62, 5161. https:/ / doi.org/10.1016/j.ijer.2013.13.06.07

McKinnon, M., Moussa-Inaty J., \& Barza, L. (2014). Science teaching self-efficacy of culturally foreign teachers: A baseline study in Abu Dhabi. International Journal of Educational Research, 66, 7889. https:// doi.org/10.1016/j.ijer.2014.03.001

Nayyar, H. A. (2016). Science education in schools. Dawn, March 4. Retrieved from https: / / www.dawn.com/news/1243391

NCES. (2019). TIMSS participating countries. Retrieved from https:/ / nces.ed.gov/timss/countries.asp

Nisar, A. (2019). What Pakistan could learn from the East Asian education systems? Pakistan Gulf Economist Business Weekly, January 21. Retrieved from http:/ / www.pakistaneconomist.com/2019/01/21 / what-pakistan-could-learn-from-the-east-asianeducation-systems/

Nurunnabi, M. (2017). Transformation from an oil-based economy to a knowledge-based economy in Saudi Arabia: The direction of Saudi vision 2030. Journal of the Knowledge Economy, 8(2), 536-564. https: / / doi.org/10.1007/s13132-017-0479-8

Organization for Economic Cooperation and Development (OECD). (2017). PISA 2015 Collaborative Problem-Solving Framework. Author.

Osborne, J. F., \& Dillon, J. (2008). Science Education in Europe. London, UK: Nuffield Foundation.

Palmer, D. (2007). What is the best way to motivate students in science? Teaching Science, 53(1), 38-42. Retrieved from https://search-proquest-com. dbgw.lis.curtin.edu.au/docview / 207230253?accou ntid=10382

Ross, J. A. (1998). The antecedents and consequences of teacher efficacy. In J. Bropy (Ed.), Advances in Research on Teaching, 7, 49-74.
Sekaran, U., \& Bougie, R. (2013) Research Methods for Business: A Skill-Building Approach (6th Edition). New York, NY: Wiley.

Settlage, J., Southerland, S. A., Smith, L. K., \& Ceglie, R. (2009). Constructing a doubt-free teaching self: Selfefficacy, teacher identity, and science instruction within diverse settings. Journal of Research in Science Teaching, 46(1), 102-125. https://doi.org/10.1002/ tea.20268

Shaukat, S. (2011). Development and validation of inservice teachers' self-efficacy beliefs in the context of Pakistan. Evaluation and Research in Education, 24(2), 121-141. https://doi.org/10.1080/09500790. 2011.556249

Shi, W. Z., He, X., Wang, Y., Fan, Z, G., \& Guo, L. (2016). PISA and TIMSS science score: Which clock is more accurate to indicate national science and technology competitiveness? Eurasia Journal of Mathematics, Science \& Technology Education, 12(4), 965-974. https://doi.org/10.12973/eurasia.2016. $1239 a$

Webb-Williams, J. (2018). Science self-efficacy in the primary classroom: Using mixed methods to investigate sources of self-efficacy. Research in Science Education, 48(5), 939-961. https://doi.org/ $10.1007 /$ s11165-016-9592-0

Welch, W.W., \& Lawrenz, F. (1982). Characteristics of male and female science teachers. Journal of Research in Science Teaching, 19(7), 587-594. https:/ / doi.org/ 10.1002/tea.3660190708

Wenner, G. (2001). Science and mathematics efficacy beliefs held by practicing and prospective teachers: A 5-year perspective. Journal of Science Education and Technology, 10(2), 181-187. https://doi.org/10.1023 / A:1009425331964

Wilson, P., \& Tan, G. (2004). Singapore teachers' personal and general efficacy for teaching primary social studies. International Research in Geographical and Environmental Education, 13(3), 209-222. https:/ / doi.org/10.1080/10382040408668516

Wiseman, A., \& Anderson, E. (2012). ICT-integrated education and national innovation systems in the Gulf Cooperation Council (GCC) countries. Computers $\mathcal{E}$ Education, 59, 607-618. https:/ / doi.org /10.1016/j.compedu.2012.02.006

\section{http://www.ejmste.com}

